\title{
PENGARUH DIABETES MELLITUS TERHADAP RESISTENSI ASPIRIN PADA PASIEN STROKE ISKEMIK DI RUMAH SAKIT BETHESDA YOGYAKARTA
}

\section{EFFECT OF DIABETES MELLITUS ON ASPIRIN RESISTANCE IN ISCHEMIC STROKE PATIENTS AT BETHESDA HOSPITAL YOGYAKARTA}

\author{
Hardi Astuti Witasari ${ }^{1,3}$, Rizaldy Taslim Pinzon ${ }^{2}$, Erna Kristin ${ }^{3}$ \\ ${ }^{1}$ Fakultas Farmasi Universitas Ahmad Dahlan, Yogyakarta \\ Jl. Prof. Dr. Soepomo, Janturan, Yogyakarta \\ ${ }^{2}$ Unit Stroke Rumah Sakit Bethesda, Yogyakarta \\ ${ }^{3}$ Fakultas Kedokteran Universitas Gadjah Mada, Yogyakarta \\ Email: whardiastuti@yahoo.co.id
}

\begin{abstract}
ABSTRAK
Pencegahan sekunder stroke iskemik dapat dilaksanakan dengan aspirin. Namun, beberapa kasus ditemukan resistensi aspirin. Penelitian ini bertujuan untuk mengkaji pengaruh diabetes mellitus (DM) terhadap risiko resistensi aspirin pada pasien stroke iskemik di Rumah Sakit Bethesda Yogyakarta. Rancangan penelitian adalah nested case control dengan kelompok kasus adalah subyek yang resisten aspirin dan kontrol adalah subyek yang responsif aspirin. Faktor-faktor yang menjadi prediktor dianalisis dengan analisis bivariat (uji chi square). Proporsi DM pada kelompok kasus lebih besar dibanding kontrol dengan OR=1,605 (CI 95\%; $0,641-4,017), p=0,155$. Faktor pasien yaitu umur $>55$ tahun $(p=0,168)$, jenis kelamin perempuan $(p=0,226)$ menunjukkan hasil yang tidak bermakna. Pasien stroke iskemik di Rumah sakit Bethesda Yogyakarta yang menderita DM tidak terbukti mempunyai risiko lebih besar mengalami resistensi aspirin dibandingkan pasien stroke iskemik yang tidak menderita DM.
\end{abstract}

Kata Kunci: Stroke iskemik, resistensi aspirin, diabetes mellitus.

\begin{abstract}
The secondary prevention of ischemic stroke can be implemented by giving aspirin. However, some cases of aspirin resistance have been found. The purpose of this study was to examine the influence of diabetes mellitus on the risk of aspirin resistance in ischemic stroke patients at Bethesda Hospital Yogyakarta. This study was using a nested case-control study design. The Cases group was subjects who resistance to aspirin therapy. The control group was subjects who response to aspirin therapy. The factors that affect the incidence of aspirin resistance were analyzed by bivariate analysis chi square test. The proportion of diabetes mellitus in resistant group was bigger than the aspirin responsive group. Its odds ratio (OR) was 1.605 (95\% CI, 0.641 to 4.017) ( $\mathrm{p}=0.155)$. Conclusion: Ischemic stroke patients at Bethesda Hospital Yogyakarta with diabetes mellitus were not proved to have a bigger risk of aspirin resistance than the patients without diabetes mellitus.
\end{abstract}

Keywords : Ischemic stroke, aspirin resistance, diabetes mellitus 


\section{PENDAHULUAN}

Stroke merupakan salah satu bentuk penyakit kardiovaskuler akut yang sering terjadi. Menurut data World Health Organization (WHO) stroke merupakan penyakit penyebab kematian nomor dua di dunia setelah penyakit jantung iskemik (WHOa, 2011). Di Indonesia penyakit kardiovaskuler menduduki posisi teratas pada tahun 1992 sampai pendataan tahun 2007 (WHOb, 2011). Berdasarkan data dasar Rumah Sakit, angka kejadian stroke adalah 63,52 per 100.000 penduduk pada kelompok usia diatas 65 tahun (DepKes RI, 2008).

Stroke dan/atau Transient Ischemic Attack (TIA) apapun sebabnya akan meningkatkan terjadinya stroke berikutnya. Dalam rentang waktu 5 tahun, risiko untuk terjadinya stroke ulang diantara para penderita stroke berkisar antara 30-43\% (Roger et al, 2011). Pencegahan sekunder terhadap stroke iskemik/ TIA dapat dilaksanakan dengan pemberian obat antiplatelet.

Aktivitas platelet merupakan faktor penting dalam patogenesis terjadinya penyakit jantung koroner dan stroke iskemik. Pemberian aspirin sebagai agen antiplatelet merupakan terapi standar untuk mencegah kejadian iskemia ini. Terapi dengan antiplatelet menurunkan 25\% kejadian vaskuler yang serius pada pasien berisiko tinggi menderita penyakit jantung koroner dan stroke iskemik (Bennet et al, 2000).

Penggunaan terapi antiplatelet masih jarang diobservasi. Pada beberapa kasus ditemukan kejadian tromboemboli pada beberapa pasien selama penggunaan aspirin. Hal ini menunjukkan bahwa pasien tersebut tidak renspon terhadap aspirin dan biasa disebut aspirin resisten. (Kim et al, 2009). Resistensi aspirin berhubungan dengan kejadian kardiovaskuler berulang dengan $\mathrm{OR}=3,8$ (CI 95\%, 2,3-6,1). Pasien resistensi aspirin mempunyai risiko lebih besar mengalami gangguan kardiovaskuler dibandingkan pasien yang responsif (Snoep et al, 2007).
Faktor comorbid pada penderita stroke iskemik berpengaruh pada resistensi antiplatelet. Pasien dengan riwayat diabetes mellitus memperlihatkan peningkatan reaktivitas dan agregasi platelet jika dibandingkan dengan orang sehat. Hal ini akan meningkatkan risiko terjadinya kejadian iskemia (Prabakharan et al, 2008).

Bioavailabilitas antiplatelet dalam tubuh juga dapat mempengaruhi respon platelet (Topcuoglu et al, 2011). Penurunan respon terhadap aspirin berhubungan dengan dosis yang terlalu rendah, buruknya absorbsi, dan rendahnya compliance (Prabakharan et al, 2008). Interaksi obat juga berpotensi menyebabkan penurunan respon platelet terhadap aspirin. Secara teoritis Penggunaan bersama dengan ibuprofen, proton pump inhibitor (PPI), statin lipofilik, dihydropyridine calcium channel blocker dapat menurunkan respon antiplatelet (Topcuoglu et al, 2011).

Besarnya angka kejadian kardiovaskuler maupun cerebrovaskuler selama terapi dengan antiplatelet sangat disayangkan. Reristensi aspirin merupakan salah satu penyebab kegagalan terapi. Rendahnya respon terhadap antiplatelet dapat beresiko terjadinya peningkatan agregasi platelet dan menimbulkan stroke berulang. Sementara itu studi tentang respon terhadap antiplatelet masih sangat terbatas. Tujuan penelitian ini adalah untuk mengkaji pengaruh diabetes mellitus terhadap risiko resistensi antiplatelet pada pasien stroke iskemik di Rumah Sakit Bethesda Yogyakarta.

\section{METODE PENELITIAN}

Jenis penelitian ini adalah observasional analitik dengan menggunakan rancangan penelitian nested case control study. Bahan penelitian yang digunakan adalah data cohort pasien stroke iskemik yang diterapi dengan aspirin dan telah melakukan tes fungsi platelet VerfyNow ${ }^{\circledR}$ (Accumetrics, San Diego, CA, USA) di Rumah Sakit Bethesda Yogyakarta. Subyek dibagi menjadi 
kelompok kasus dan kontrol sesuai kriteria inklusi dan eksklusi. Kelompok kasus adalah pasien yang resisten dengan aspirin. Kelompok kontrol adalah pasien yang mempunyai respon terhadap aspirin Resistensi aspirin ditunjukkan dengan nilai aspirin reaction unit (ARU) $\geq 550$ dan responsif ditunjukkan dengan ARU $<550$ (Kim et al, 2009). Pasien dibawah 18 tahun dikeluarkan dari subyek penelitian.

Penelitian dimulai setelah memperoleh ethical clearence dari komisi etik penelitian Fakultas Kedokteran Universitas Gadjah Mada Yogyakarta. Jumlah sampel kelompok kasus dan kelompok kontrol dihitung menggunakan aplikasi Duppon, dengan : kesalahan tipe I sebesar 5\%, hipotesis satu arah dan kesalahan tipe II sebesar 20\%. Proporsi kejadian diabetes mellitus pada kelompok kontrol sebesar 27\% (Ozben et al, 2011). Perbandingan jumlah sampel kelompok kasus dan kelompok kontrol adalah 1:2. Pada perhitungan dengan aplikasi Duppon diperoleh jumlah sampel minimal kelompok kasus sebesar 21 subyek dan 42 subyek untuk kelompok kontrol. Pada penelitian ini digunakan 30 subyek kelompok kasus dan 80 subyek kelompok kontrol.

Analisis data hasil penelitian ini dilakukan menggunakan software pengolah data. Analisis deskriptif untuk variabel kategorik disajikan dalam bentuk frekuensi dan prosentase sedangkan variabel numerik disajikan dalam bentuk rerata dan standar deviasi (SD) pada tabel dan narasi. Data diuji karakteristiknya pada kelompok kasus dan kontrol. Data yang bersifat numerik digunakan uji t sedangkan untuk data yang bersifat kategorikal digunakan chi square. Analisis bivariat digunakan untuk menguji hipotesis dengan variabel yang diuji yaitu riwayat diabetes mellitus terhadap kejadian resistensi aspirin. Analisis bivariat juga digunakan untuk menganalisis faktor-faktor penyerta kejadian resistensi aspirin yaitu umur, jenis kelamin, dan interaksi obat.

\section{HASIL DAN PEMBAHASAN}

\section{Karakteristik subyek penelitian}

Populasi dalam penelitian ini adalah pasien stroke iskemik yang diterapi dengan aspirin sebagai antiplatelet dan melakukan tes fungsi platelet VerfyNow ${ }^{\circledR}$ (Accumetrics, San Diego, CA,USA) di Rumah Sakit Bethesda Yogyakarta. Subyek dengan nilai aspirin reaction unit (ARU) $\geq 550$ dikategorikan sebagai resisten aspirin dan dimasukkan dalam kelompok kasus. Subyek dengan nilai ARU $<550$ dikategorikan sebagai responsif aspirin dan dimasukkan dalam kelompok kontrol . Keseluruhan subyek dalam penelitian ini adalah 110, terdiri atas 30 pasien kelompok resisten dan 80 pasien responsif. Nilai rata-rata ARU 594,53 $\pm 37,84$ untuk kelompok resisten dan 453,13 $\pm 50,70$ untuk kelompok responsif. Karakteristik dasar subyek dapat dilihat pada Tabel I.

Analisis statistik memberikan hasil bahwa pada karakteristik dasar subyek dan hasil pemeriksaan laboratorium tidak memberikan perbedaan yang bermakna pada kelompok resisten dan responsif. Pemeriksaan laboratorium dilakukan pada saat subyek mengalami kejadian iskemia.

\section{Analisis bivariat hubungan diabetes mellitus terhadap resistensi aspirin}

Pada penelitian ini hubungan variabel bebas (diabetes mellitus) dan variabel terikat (respon terhadap aspirin), dianalisis dengan uji chi squqre pada taraf signifikan $\alpha=0,05$ sedangkan untuk melihat seberapa besar terjadinya outcome yang mungkin terjadi pada populasi dapat dilihat nilai odds ratio (OR) dengan confidece interval (CI) 95\%. Hubungan riwayat diabetes mellitus pada pasien stroke iskemik dengan kejadian resistensi aspirin ditampilkan pada Tabel II.

Pada penelitian ini, proporsi diabetes mellitus pada kelompok resisten lebih besar dibandingkan kelompok sensitif aspirin. 
Tabel I. Karakteristik dasar subyek pada kelompok resisten dan responsif

\begin{tabular}{|c|c|c|c|}
\hline \multirow[t]{2}{*}{ Karakteristik } & \multicolumn{2}{|c|}{$\underline{\text { Resisten aspirin } \quad \text { Responsif aspirin }}$} & \multirow[t]{2}{*}{$\mathrm{p}$} \\
\hline & $\mathrm{n}=30(\%)$ & $n=80(\%)$ & \\
\hline Umur & $63,31 \pm 12,71$ & $63,38 \pm 10,95$ & 0,484 \\
\hline Jenis Kelamin Perempuan & $14(46,7)$ & $31(38,8)$ & 0,226 \\
\hline Gangguan Jantung & $6(20,0)$ & $23(28,8)$ & 0,177 \\
\hline GDS (mg/dL) & $161,13 \pm 81,53$ & $157,88 \pm 96,05$ & 0,483 \\
\hline Kolesterol (mg/dL) & $195,81 \pm 63,27$ & $195,54 \pm 47,22$ & 0,491 \\
\hline Trigliserid (mg/dL) & $124,58 \pm 77,91$ & $156,97 \pm 119,05$ & 0,097 \\
\hline HDL (mg/dL) & $59,25 \pm 50,40$ & $45,32 \pm 21,53$ & 0,345 \\
\hline LDL (mg/dL) & $117,8 \pm 53,63$ & $127,12 \pm 44,17$ & 0,192 \\
\hline $\mathrm{AL}(/ \mu \mathrm{L})$ & $9103 \pm 3383$ & $8675 \pm 3632$ & 0,257 \\
\hline $\mathrm{AT}(/ \mu \mathrm{L})$ & $293037 \pm 139130$ & $277191 \pm 114821$ & 0,460 \\
\hline SGOT $(\mu / L)$ & $23,11 \pm 18,75$ & $24,52 \pm 14,95$ & 0,085 \\
\hline SGPT $\quad(\mu / L)$ & $26,79 \pm 24,94$ & $21,94 \pm 10,79$ & 0,426 \\
\hline Ureum (mg/dL) & $32,51 \pm 15,87$ & $29,98 \pm 11,49$ & 0,193 \\
\hline Creatinin (mg/dL) & $1,29 \pm 1,01$ & $1,03 \pm 0,37$ & 0,462 \\
\hline
\end{tabular}

*Signifikan jika $p<0,05$

GDS: Gula Darah Sewaktu; HDL: High Density Lipoprotein; LDL: Low Density Lipoprotein, SGOT: Serum Glutamic-Oxaloacetic Transaminase; SGPT: Serum Glutamic-PyruvicTransaminase; AL: Angka Leukosit; AT: Angka Trombosit.

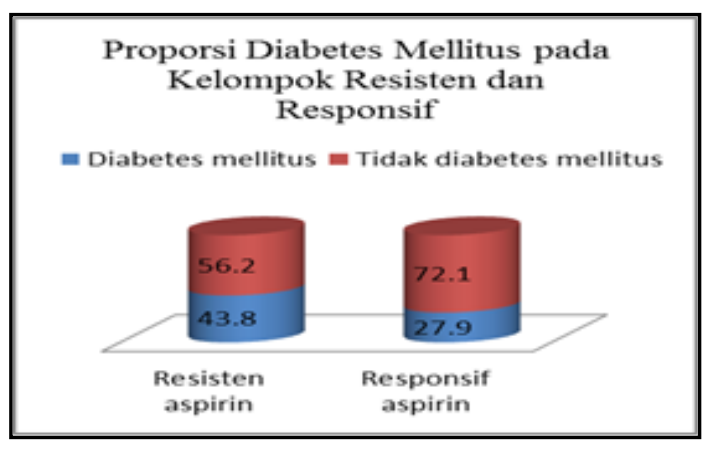

\section{Gambar 1. Proporsi diabetes mellitus pada kelompok resisten dan responsif}

Nilai odds ratio (OR) nya sebesar 1,605 (CI 95\%, 0,641-4,017). Namun perbedaan tersebut tidak bermakna secara statistika $(\mathrm{p}=0,155)$. Berdasarkan analisis bivariat dapat terlihat bahwa diabetes mellitus tidak terbukti secara statistik menjadi faktor risiko kejadian resistensi aspirin. Hal ini dapat dilihat pada Gambar 1. Hasil penelitian ini sesuai dengan peneitian penelitian sebelumnya yang juga dilakukan pada pasien stroke iskemik.
Proporsi diabetes mellitus pada kelompk resisten lebih besar dibandingkan kelompok sensitif, namun tidak berbeda bermakna (Kim et al, 2009; Ozben et al, 2011). Penelitian lain yang dilakukan Kilickesmez et al. (2012) pada subyek dengan gangguan ginjal juga memberikan hasil yang sama. Pada subyek yang mengalami gangguan ginjal, proporsi diabetes mellitus pada kelompok resisten lebih besar dibandingkan kelompok sensitif, meskipun perbedaannya tidak bermakna.

\section{Pembahasan}

Diabetes mellitus termasuk dalam faktor prediktor kejadian resistensi aspirin. Hal ini didasarkan pada terjadinya peningkatan aktivitas dan agregasi platelet pada penderita diabetes mellitus (Prabakharan et al, 2008; Angiolilo et al, 2009). Peningkatan aktivitas dan agregasi platelet ini dapat menyebabkan penurunan respon platelet. Beberapa mekanisme resistensi antiplatelet pada penderita diabetes mellitus 
Tabel II. Analisis bivariat hubungan diabetes mellitus terhadap resistensi aspirin

\begin{tabular}{llllll}
\hline Status & Resisten & Responsif & OR & CI & $p$ \\
& $\mathrm{n}=30$ & $\mathrm{n}=80$ & & & \\
\hline Diabetes Mellitus & $10(33,3 \%)$ & $19(23,8 \%)$ & 1,605 & $0,641-4,017$ & 0,155 \\
Tidak Diabetes mellitus 20 & $(66,7 \%)$ & $61(76,3 \%)$ & & & \\
\hline "signifikan bila $p<0,05$ & & & & &
\end{tabular}

telah diketahui. Immature platelet fraction (IPF) pada penderita diabetes mellitus $16 \%$ lebih tinggi dibandingkan dengan yang tidak mengalami diabetes mellitus $(\mathrm{P}=0,060)$. Trombosit yang immature berpotensi meningkatkan haemostatik dan dapat menyebabkan pembentukan trombus (Grove et al, 2009).

Diabetes mellitus berkaitan juga dengan hiperfibrinogenemia dan hiperlipidemia. Peningkatan kadar fibrinogen sering terjadi pada penderita diabetes mellitus karena keadaan peradangan sistemik, obesitas viseral, dan tingginya kejadian infeksi. Tingginya kadar fibrinogen dapat mempengaruhi pembentukan trombus (Gaborit et al, 2009). Kondisi hiperlipidemia mendukung terjadinya disfungsi endotel sehingga menyebabkan peningkatan reaktifitas platelet dan terjadinya trombosis (Simon et al, 2007).

Penelitian ini masih terdapat kelemahan. Faktor yang belum dapat diteiti seperti sangat dimungkinkan dapat mempengaruhi hasil penelitian. Studi lebih lanjut mengenai faktor yang berpengaruh pada resistensi aspirin sangat diperlukan.

\section{KESIMPULAN}

Pada penelitian ini, pasien stroke iskemik di Rumah sakit Bethesda Yogyakarta yang menderita diabetes mellitus tidak terbukti mempunyai risiko lebih besar mengalami resistensi aspirin dibandingkan pasien stroke iskemik yang tidak menderita diabetes mellitus.

\section{UCAPAN TERIMA KASIH}

Terima kasih yang sebesar besarnya kami sampaikan kepada : Rumah Sakit Bethesda Yogyakarta yang telah memberikan ijin sebagai tempat penelitian.

\section{DAFTAR PUSTAKA}

Angiolillo, D.J., Suryadevara, S. 2009. Aspirin and Clopidogrel: Efficacy and Resistance in Diabetes Mellitus. Best Pract Res Clin Endocrinol Metab Vol. 3: 375-388.

Bennett, C.L., Connors, J.M., Carwile, J.M., Moake, J.L., Bell, W.R., Tarantolo, S.R., et al. 2000. Thrombotic Thrombocytopenic purpura associated with Clopidogrel. N Engl J Med 363: 1909-1917.

Departemen Kesehatan Republik Indonesia. 2008. Riset Kesehatan Dasar (Riskesdas) 2007. Badan Penelitian dan Pengembangan Kesehatan Departemen Kesehatan Republik Indonesia. Jakarta.

http://www.litbang.depkes.go.id/riskesdas2/pu blic.html/index.php

Gaborit, B., Frere, C., Cuisset, T., Alessi, M.C., Dutour, A. 2009. Enhanced PostClopidogrel Platelet Reactivity in Diabetic Patients is Independently Related to Plasma Fibrinogen Level but not to Glycemic Control. J Thromb Haemost Vol. 11: 1939-1941 
Grove, E.L., Hvas, A.M., Kristensen, S.D. 2009. Immature Platelets in Patients with Acute Coronary Syndromes. Thromb Haemost Vol. 1: 151-156.

Kim, H., Lee, H.K., Han, K., Jeon, H.K. 2009. Prevalence and Risk Factors for Aspirin and Clopidogrel Resistance in Patients with Coronary Artery Disease or Ischemic Cerebrovascular Disease. Ann Clin Laboratory Sc Vol. 3: 289-294.

Lee, P.Y., Chen, W.H., William, N., Cheng, X., Kwok, J.Y., Tse, H.F., Lau, C.P. 2005. Low-Dose Aspirin Increase Aspirin Resistance in Patient with Coronary Artery Disease. Am J Med Vol. 7: 723-727.

Ozben, S., Ozben, B., Tanrikulu, A.M., Ozer, F., Ozben, T. 2011. Aspirin Resistance in Patients with Acute Ischemic Stroke. Journal Neurology 258:1979-1986.

Prabhakaran, S., Wells, K.R., Lee, V.H., Flaherty, C.A., Lopes, D.K. 2008. Prevelence and Risk Factors for Aspirin and Clopidogrel Resistance in Cerebrovascular Stenting. Am $J$ Neuroradiol Vol. 29: 281-285.

Roger, V.L., Go, A.S., Jones, D.M., Adams, R.J., Berry, J.D., Brown, T.M., Camethon, M.R., Dai, S., et al. Heart Disease and Stroke Statistics-2011 Update: A Report From the American Heart Association. Circulation 123: 18209.
Simon, D.I., Schmaier, A.H 2007. Sweet and Sticky: Diabetic Platelets, Enhanced Reactivity, and Cardiovascular Risk. $J$ Am Coll Cardiol Vol.16: 1548-1550.

Snoep, J.D., Hovens, M.C., Eikenboom, J.C., Bom, J.G., Huisman, M.V. 2007. Prevalence of Persistent Platelet Reactivity Dispite Use of Aspirin: A Systematic Review. Arch Intern Med Vol. 15: 1593-1599.

Topcuoglu, M.A., Arsava, E.M., Hakan, A. 2011. Antiplatelet Resistance in Stroke. Expert Rev. Neurother Vol. 2: 251-263.

Watala, C., Pluta, J., Golanski, J. 2005. Increased Protein Glycation in Diabetes Mellitus is a Associated with Decreased Aspirin-Mediated Protein Acetylation and Reduced Sensitivity of Blood Platelets to Aspirin. J Mol Med Vol. 2: 148-158.

World Health Organization. 2011. Top Ten Causes of Death.WHO Fact Sheet.

www.who.int/mediacentre/factsheets/fs310/en /index.html

World Health Organization. 2011. Stroke, Cerebrovascular Accident. WHO Fact Sheet.

www.who.int/mediacentre/factsheets/fs317/en /index.html 